\title{
DIE VERHOUDING VERBOND, BESNYDENIS EN DOOP
}

\author{
Prof. J. L. Helberg
}

In hierdie artikel word op die Ou Testament gekonsentreer, omdat die openbaringshistoriese agtergrond en verband besonder beiangrik is vir ons onderwerp.

\section{INLEIDING: DIE EENHEID VAN OU EN NUWE VERBOND}

Besnydenis en doop behoort tot afsonderlike bedelings, naamlik dié van die ou verbond en diè van die nuwe verbond onderskeidelik. Die verhouding tussen besnydenis en doop word bepaal deur die verhouding tussen die twee bedelings.

On die regte perspektief op besnydenis en doop te hê, moet daar rekening gehou word met die eenheid binne die Ou Testament, die eenheid binne die verbond en die eenheid tussen Ou Testament en Nuwe Testament. Jesus Christus is nie bykomstig tot die verbond nie, en so is ook die Christelike doop nie bykomstig tot die verbond nie.

As dié eenheid vir 'n mens vasstaan, hoef jy nie in die eerste plek na teksbewyse te soek om die verbond tussen besnydenis en doop in te sien nie.

Aan die ander kant, wie die wesenlike verband tussen doop en besnydenis ontken, ontken dat die gelowiges van die ou en die nuwe bedeling wesenlik in dieselfde verhouding tot God gestaan het.

Die punt in geding raak dus nie net die kontinuïteit van die verbondsteken nie, maar van die verbondsverhouding self. Jesus self sê dat Abraham in 'n besondere verhouding tot Hom gestaan het, die dag van sy koms gesien en het hom daarin verbly het (Joh. 8: 56-58).

In hierdie verband sal ons aantoon dat, watter verbygaande elemente daar in die verbond van God met Israel in die ou bedeling mag wees, die wese van die verbond onveranderlik is. Die verbond bestaan wesenlik daarin dat God Abraham en sy nakomelinge se God sal wees en dat hulle sy volk sal wees (Gen. $17: 7-9$ ). Hy neem hulle as sy eie aan en sorg vir hulle in liefde en trou. en hulle dien Hom. Dit geld van Abraham se stoflike nakomelinge maar ook van sy geestelike nakomelinge uit die nasies. God sê vir Abraham dat al die nasies van die aarde in hom geseën sal word (Gen. $12: 3 ; 22: 18$ ). In Rom. $4: 11,12$ word Abraham dan ook die vader van al die gelowiges genoem.

Die nuwe bedeling of nuwe verbond verskil dus nie wesenlik van die oue nie. Daar moet met die kontinuiteit deeglik rekening gehou word. ${ }^{1}$

Nuwe- en Ou-Testamentiese bedeling moet nie uiteen geruk word asof 'n mens daarin met twee verskillende verbonde of testamente of koninkryke te doen het nie. Dit moet veral nie so gesien word dat die ou bedeling ' $n$ verbondsbedeling en die nuwe bedeling 'n koninkryksbedeling is nie. Daarmee word 'n te skerp skeiding gemaak tussen ou en nuwe bedeling, asook 'n te skerp skeiding tussen verbond en 
koninkryk. Soos die verbond in ou en nuwe bedeling wesenlik dieselfde is, is die koninkryk ook in albei bedelings wesenlik dieselfde. Wat die verhouding verbond-koninkryk betref, moet die volgende onthou word: watter onderskeid daar tussen hierdie twee begrippe mag bestaan, hulle is daarin gelyk dat dit om God se heerskappy gaan wat nie alleen gehoorsaamheid by die mens bewerkstellig nie, maar ook vertroue, geloof, en dankbaarheid. ${ }^{2}$ Die koninkryk het 'n verbondskarakter. Dit gaan om 'n heerskappy in liefde, in vergewende genade. Dit is ' $n$ lewewekkende heerskappy: God voorsien self in wat $\mathrm{Hy}$ eis, Hyself verander die mens se hart en bewerkstellig in die onwillige en onmagtige sondaar 'n nuwe lewe van oorgawe aan Hom. Dit geld van die ou bedeling sowel as van die nuwe bedeling.

Tussen ou en nuwe bedeling is daar ' $n$ eenheid en dié eenheid is openbaringshistories van aard.

\section{2 'n OPENBARINGSHISTORIESE EENHEID}

Daar word in die Ou Testament sterk nadruk gelê op die verlede. Dikwels word verwys na die verbondsverhouding waarin God in die verlede tot die aartsvaders gestaan het, en dit word gestel as grond vir sy optrede in die hede. Hy openbaar Hom aan Moses as die God van Abraham, Isak en Jakob" (Gen. 26:24; $28: 13$; Eks. 3:6), en die verbondsverhouding wat daarmee uitgedruk word, is van grondliggende betekenis vir sy bevryding van sy volk uit Egipte (Eks. $3: 6,15)$.

Dikwels word daar in die Ou Testament ook verwys na die uittog uit Egipte en word God se huidige en selfs toekomstige optrede en sy verlossingsdaad daaraan gekoppel (bv. Jes. $63: 11$; Jer. $23: 5-8$; Miga $7: 15) .^{3}$

"Onthou" of "gedenk" is een van die sleutelbegrippe in die Ou Testament. Die Israeliete moet dit ook nie alleen self onthou nie, maar moet dit aan hulle kinders leer (Deut. 6: 7,20 ). Daar moet dus 'n sterk historiese besef gekweek word, onder andere in verband met die pasga (Eks. 12:24 e.v.) Die Ou Testament sien die verhouding tussen God en mens dus nie eksistensialisties nie, nie volledig toegespits op hier en nou nie, veral nie volledig toegespits op die mens se inisiatief hier en nou nie. Die Ou Testament benadruk God se inisiatief wat sy wortels ver terug in die geskiedenis het. God is nie net ' $n$ God van vandag nie, ook nie in wat Hy nou vir of met die gelowiges doen nie. Hy openbaar Hom op so 'n manier in sy verlossingswerk aan die gelowiges dat hulle 'n wydsheid van perspektief kry, 'n perspektief wat ver oor die hier en nou strek en waarin God geloof word vir wat Hy van lank gelede af al besig is om te doen.

Israel is egter nia net opgeroep om te onthou nie maar ook om te onderhou. God se werksaamheid en sy gebooie geld nie slegs van lank gelede nie maar vorm die grondslag vir sy optrede in die hede. Moses praat met die Israeliete 'n geslag ná die verbondsluiting by Horeb en sê: "Die Here onse God het by Horeb met ons 'n verbond gesluit. Met ons vaders het die Here hierdie verbond nie gesluit nie, maar met ons self, ons wat vandag hier almal in die lewe 
is" (Deut. $5: 2,3$ ). Die Ou Testament sien die verbondsverhouding tussen God en sy volk dus nie historisisties, asof dit net historiese waarde in die sin van verbygaande waarde gehad het nie. God is ook in die hede aan die werk en staan nou in 'n lewende, werksame verhouding met sy volk.

Maar Israel is nie net opgeroep om te onthou en te onderhou nie; hulle moes ook aanhou, hulle moes die oog in verwagting en vertroue op die toekoms rig. God se gebooie en sy verbond, waarvan hier bo sprake was, word gegee sodat Israel dit kan onderhoud in die iand waarheen hulle op pad is (Deut. 6:3). Wanneer die verbond met Abraham gesluit word, word ook die nageslag in die visier gehou (Gen. 17:7). Dwarsdeur die Ou Testament word die oog op die toekoms gevestig. Die Ou Testament is oop na die toekoms toe." Die Ou Testament sien die verbondsverhouding tussen God en mens dus nie as dié van gearriveerdheid nie. Daar is nie plek vir 'n verlammende ortodoksisme of enige stagnasie nie. God gaan met sy volk voorwaarts.

Die openbaringshistoriese eenheid van God se werk verleen dus aan die verbondsverhouding tussen God en mens veiligheid, aktualiteit en lewenskragtigheid, en 'n lewende hoop op die toekoms.

Die openbaringshistoriese aard van God se verlossingswerk behels nie net dat Hy Hom histories geopenbaar het nie, in die geskiedenis geopenbaar het nie, dat sy openbaring daarmee klaar is nie. Inteendeel, dit behels dat $\mathrm{Hy}$ Hom nou nog openbaar en ook in die toekoms gaan openbaar, en wel deur die kontinuz̆teit van die persoonlike verbondsverhouding waarin Hy met die gelowiges staan. Sy optrede is opgeteken, op Skrif gestel, nie maar as 'n historiese stuk, iets oor die verlede nie, maar as openbaring vir nou. Anders gestel, die Skrif bevat nie net wat God oor die verlede, 6or die hede en ór die toekoms gesê het nie, maar ook wat Hy vír die leser vandag sê. Dit is openbaring waarmee God deur sy Heilige Gees Hom nóu aan die gelowiges openbaar en gelowige reaksie verwag. En hierdie gelowige reaksie behels 'n gelowige erkenning van God se optrede nie alleen nou nie maar ook in die verlede en in die toekoms. So moet ons ook die hele saak van die doop benader. Die openbaringshistoriese aard van God se verlossingswerk moet ook in ons verhouding tot God uitkom en 'n kenmerk wees van ons lewe as gedooptes: geankerdheid in God se werk in die verlede, lewenskragtigheid deur God se verhouding met ons nou, en 'n lewende hoop op die toekoms.

Laat ons nou in 'n kort oorsig kyk na die verbond in die $\mathrm{Ou}$ Testament.

3. VERBOND

Voor die verbondsluitings bespreek word, moet daarop gewys word dat hier nie ingegaan kan word op die verskillende betekenisse wat die woord verbond in die Hebreeus of selfs net in die Ou Testament het en wat nie almal iets met 'n verbond te maak het nie. Ons sal slegs kyk na die soont verbond wat vir die doel van hierdie voordrag van direkte belang is. Die betekenis daarvan word bepaal deur hoe dit deur die Ou Testament self gebruik is en moet dus uit die verband vasgestel word. 
Verbond behels hier dat God in sy verkiesende genade die mens, of 'n groep mense, in 'n bepaalde verhouding met Hom stel wat nie net van momentele betekenis is nie, maar van blywende betekenis. God onderneem in die verbond sekere verantwoordelikbede teenoor die mens en bepaal ook sekere verantwoordelikhede wat die mens vrywillig teenoor Hom moet nakom.

Die verbondsverhouding tussen God en mens is moontlik deurdat die mens na die beeld van God geskape is (Gen. $1: 26,27$ ). Dit impliseer in 'n sekere sin 'n verbondsverhouding tussen God en die mens; die mens staan in 'n innige verhouding met God maar is nie aan God verwant nie. Die mens is 'n blote skepsel, en God is die Skepper. Israel se buurnasies het nie aan die verhouding tussen hulle en hulle gode in terme van 'n verbond gedink nie. Die gode was stamgode of volksgode en kon dus nie los van die betrokke groep gedink word nie. ${ }^{6}$

By Israel daarenteen speel die verbond tussen God en sy volk 'n groot rol. Daar is geen sprake van 'n outomatiese verband tussen God en Israel nie, en verder word dié verhouding gekenmerk deur innigheid en tegelykertyd deur afstand. Alle inisiatief kom van God (monopleuries), tog word van die mens 'n antwoord verwag. Israel is ten volle van God afhanklik, daar is geen sprake van 'n soort gelyke verbondsvennootskap tussen hulle nie.7

Dit is baie belangrik om daarop te let dat die verbond tussen God en die mens iets anders is as 'n verdrag of 'n formele ooreenkoms. Die verbond is nie iets wat op homself 'n bestaan het, 'n struktuur wat bepaal wie wel aan God behoort en wie nie aan Hom behoort nie. Die verbond is nie iets selfstandigs, iets wat tussen God en die mens staan en dus 'n afstand tussen God en mens bring nie. Die verbond gee wel plegtig uitdrukking aan die verbondenheid waarin God die mens tot Hom stel deur sy verkiesende genade, sonder enige verdienste van die mens. Hierdie verbondenheid bewerkstellig en vereis tegelykertyd dat die mens bewustelik en uit liefde tot God in ooreenstemming daarmee leef. God is lewe. Verbondenheid met God gee lewe: die ware lewe, wat dankbaarheid, geloof, liefde, gehoorsaamheid, ens. insluit. As hierdie dinge ontbreek, bewys dit dat daar nie 'n ware verbondenheid is met God wat lewe is en lewe gee nie. In so 'n geval werk die verbondenheid die ondergang, net soos by die son wat lewe wek maar in sommige gevalle 'n verskroeiende effek het. God is ook die handhawer en regter in die verbond omdat daar geen hoër regter as $\mathrm{Hy}$ is nie.

Die verbond draai dus om die verbondenheid met God; en dit is Gód wat in beheer is en wat optree. 'n Mens moet dus oppas dat jy die verbond nie as iets onpersoonliks benader en so primêr stel dat die verbond die bepalende faktor word en prakties God vervang nie. Die verhouding tussen God en die gelowige is wel nie maar 'n oombliksverhouding, 'n oombliksverbondenheid nie en is nie bloot indiwidualisties nie; daar is kontinuiteit in en dit word vergestalt in die verbond. Die verbond is egter nie iets selfstandig nie, nie plaasvervangend vir die verhouding of verbondenheid tussen God en mens nie, maar is die vergestalting en beseëling daarvan. 


\section{DIE VERBOND VAN GOD MET NOAG}

Die eerste verbond waarvan ons uitdruklik in die Ou Testament hoor, is dié van God met Noag. (Dit het wel 'n heel besondere aard omdat dit 'n eensydige toesegging of bepaling veral en ook met die natuur opgerig word (Gens. 9:10 e.v.). In hierdie verbond betoon God sy genade aan die mens van wie God sê dat hy deur en deur sondig is (Gen. 8:21). God bevestig die mens se koningskap oor die skepping en benadruk tegelykertyd dat $\mathrm{Hy}$, God self, die enigste beskikker oor die bloed, die lewe, van mens en dier is (Gen. 9:4-6). God self is koning oor hierdie sondige en gebroke skepping, en God is ' $n$ genadige God. Die vernietigende oordeel wat oor die wêreld gekom het, gaan Hom ter harte; Hy sal nie weer 'n sondvloed oor die wêreld laat kom nie.

Soos in die res van die Ou Testament word God se verbondsoptrede hier gekenmerk deur kontinuïteit met die verlede, deur absolute Goddelike inisiatief teenoor die mens, en deur vergewende genade en liefde wat lewe uit ondergang en dood wek. Soos elders word hier ook eise aan die mens gestel. Anders as in die verbond met Abraham, Moses en Dawid, is die verbond hier met die hele mensdom en die skepping opgerig.

Die teken van hierdie verbond van God met die mens is die reënboog. Hierdie teken sal die mens herinner aan hierdie verbond, en dit sal ook vir God herinner sodat $\mathrm{Hy}$ volgens hierdie verbond sal optree (Gen. 9:12-17) (vgl. ook Eks. 28:29 e.v. 28:35). Dit beteken nie dat God anders die verbond sou vergeet nie. Tog wil Hy herinner word - net soos $\mathrm{Hy}$ aan die mens se nood herinner wil word deurdat die mens tot Hom moet bid, hoewel Hy tog vanself die mens se nood, behoefte en alles wat in sy hart is voortdurend ken. Al sien en weet God alles, Hy wil herinner word, want $\mathrm{Hy}$ is nie 'n blote krag of mag wat onpersoonlik funksioneer nie, maar 'n persoonlike God. Hy staan in 'n persoonlike verhouding met die mensdom. Dit geld ook en veral vir die ander verbondstekens in ou en nuwe bedeling. Daarom is nalatigheid om die verbondsteken aan te bring, 'n ernstige saak met ernstige gevolge.

\section{GOD SE VERBOND MET ABRAHAM}

Die verhouding tussen God en mens is ernstig aangetas met die bou van die stad en toring van Babel. Die mensdom wou los van God eenheid, mag en onsterflike roem verwerf. Omdat hulle die rug op God gekeer het, keer Hy die rug op hulle. Tog behou Hy sy band met die mensdom, en wel deur 'n oorblyfsel. God roep vir Abraham, maak met hom 'n nuwe begin en rig met hom 'n verbond op. In hom sal al die nasies van die aarde uiteindelik geseën word. God laat dic mensdom nie vaar nie, daar is kontinuiteit in sy werk. Die mensdom word verlos, die ware kern van die mensdom.

Die verbond wat God met Abraham oprig, bevat verskillende stoflike en geestelike beloftes, ${ }^{8}$ soos 'n talryke nageslag (Gen. 15: 5; $17: 2,4,5$ ), die land Kanaän as besitting (Gen. $15: 7,18 ; 17: 8$ ) en 'n seën vir al die geslagte van die aarde (Gen. $18: 18 ; 22: 18$ ), maar dit gaan veral om die blywende verhouding waarin God Hom tot 
Abraham en sy nageslag stel, naamlik om hulle God te wees (Gen. $17: 7$ ).

God stel ook eise in die verbond, Hy vra absolute en onvoorwaardelike gehoorsaamheid. Abraham moet die verbond nakom, die verbondsteken getrou laat aanbring aan die lede van die verbond (Gen. $17: 9$ e.v.) en opreg, naby God lewe (Gen. 17:1). Abraham word selfs op die proef gestel of hy bereid is om sy seun Isak aan God te offer (Gen. 22).

Abraham se gehoorsaamheid is 'n vrug van die geloof, en nie gelc of in die algemeen nic, selfs nie geloof in God sonder meer nie, maar die geloof dat God in alles alle inisiatief het en dit deurvoer, ook in die mens se verlossing. God se optrede, sy verlossingswerk, is skeppend, of beter gestel, herskeppend, lewewekkend, uit die mens self is daar geen moontlikheid van verlossing nie. God roep daarom juis vir Abraham, wie se huwelik met Sara nie kinders kan hê nie. Abraham glo dat God lewe uit die dood kan wek (vgl. ook Rom. $4: 17-21)$. Om hierdie rede is hy ook gewillig om sy seun te offer: in die geloof dat hierdie kind wat uit verstorwenheid gebore is en aan wie die beloftes verbind is, deur God se lewewekkende mag lewendig gemaak sal word (vgl. ook Hebr. 11:17-19). Hierdie optrede van Abraham maak dat God die verbondsbeloftes herhaal (Gen. $22: 16-22$ ). Die verbond hang dus saam met die geloof, en wel die geloof dat God lewewekkende krag het en dat Hy verlos deur lewewekking uit die dood. ${ }^{\circ}$ Dit geld ook geestelike lewewekking, waarvan gehoorsaamheid 'n vrug is.

God vra dus gehoorsaamheid in die verbondsverhouding, maar die gehoorsaamheid is tog ten diepste die vrug van sy genadige optrede. So vra God in die verbondsverhouding ook geloof, geloof in sy lewewekkende werksaamheid maar hierdie geloof is tog die vrug van sy lewewekkende werksaamheid. As God nie lewewekkend optree nie, kum daar niks, ook nie geloof nie. Geloof kan nie die grond van God se lewewekkende werksaamheid wees nie. Inteendeel, Gód se lewewekkende werksaamheid sit alles aan die gang, ook die geloof in hierdie werksaamheid. Die grond vir God se lewewekikende optrede is sy onpeilbare, soewereine, verkiesende genade. So is Abraham self deur God geroep. Daar word geen motivering voor gegee nie, net die feit van God se vrymagtige optrede gestel: "Gaan jy uit jou land en uit jou familie en uit jou vader se huis na die land wat Ek jou sal wys. En Ek sal jou 'n groot nasie maak en jou seën en jou naam so groot maak dat jy 'n seën sal wees. En Ek sal seën diegene wat jou seën, en hom vervloek wat jou vervloek; en in jou sal al die geslagte van die aarde geseën word" (Gen. $12: 1-3$ ). God regeer. Hy vat die mens onweerstaanbaar aan sy hand en lei hom, en $\mathrm{Hy}$ vat die mens tegelykertyd onweerstaanbaar in sy hart en beweeg hom tot geloof en gehoorsaamheid, tot 'n lewe van persoonlike oorgawe aan Hom. Hierdie absolute inisiatief van God, hierdie verkiesende lewewekkende vrymag, maak dat ook die gelowiges se kinders ingeskakel word, al kan hulle nog nie van hulle geloof getuig nie.

Die verbond behels nie net genade nie, maar ook oordeel oor ongenoorsaamheid. ${ }^{10}$ Hierdie oordeel word by die verbondsluiting 
geimpliseer deurdat die Here tussen die stukke van die verdeelde offerdiere deurgaan (Gen. 15:9-10,17). Die stukke simboliseer dat die verbondsbreker ook in stukke gekap sal word. Die verbond is ' $n$ ernstige saak, 'n saak van lewe en dood: daar is wonderdadige verlossing vir hom wat glo in God se beloftes en daarvolgens lewe, maar dood vir die verbondsbreker. Daar is geen moontlikheid van 'n onbetrokke houding nie. Dieselfde geld van die doop in die nuwe bedeling (Mark $16: 16$ ).

Die verbondsluiting is so ' $n$ ingrypende saak dat God by hierdie geleentheid aan Abraham en Sara ander name gee as wat hulle eers gehad het (Gen. $17: 5$ ).

God stel die besnydenis in as teken van die verbond. Abraham en alle manlike kinders moet die teken ontvang. Dit moet by die kinders op die agste dag ná die geboorte gebeur en geld vir alle lede van Abraham se huishouding, ook die slawe (Gen. 17:12). Niemand mag hiervan uitgesluit word nie. Daar is geen moontlikheid om onbetrokke te bly teenoor God se beloftes van genade, sy eis om gehoorsaamheid en sy oordeel oor verbondsoortreding nie. Dit is God se vrymagtige opdrag, en Hy moet as absolute heerser erken en eerbiedig word. As iemand nie aan die eis om besny te word, voldoen nie, moet hy onder sy volksgenote uitgeroei word (Gen. $17: 4$ ), want dit beteken verwerping van die verbond en van God se soewereiniteit.

Volgens hierdie geskiedenis het Abraham eers geglo, eers daarna is hy besny. Hy is deur die geloof geregverdig, nie deur die besnydenis nie (Gen. 15:6). Die besnydenis was slegs 'n beseëling van die geregtigheid van die geloof (vgl. ook Rom. 4:11, 12). Sy regte verhouding tot God is beseël, en hierdie regte verhouding tot God is uit genade deur God gegee, en is deur die geloof omhels. Die geloof beteken dat Abraham aanvaar wat God gee, ten volle op God vertrou en homself, sy hele lewe, aan God oorgee. ${ }^{11}$

Die boek Deuteronomium sê dan ook dat die eintlike saak die besnydenis van die hart is, dit is om die sonde af te lê en God met jou hele hart en siel lief te hê (Deut. $10: 12,16 ; 30: 6$; vgl. ook Jer. $4: 4 ; 9: 25,26)$. Dit raak wat Jesus self die kern van die wet en die profete die kern van die Ou Testament, die ou verbond, noem (Matt. 22:37-40). Dit is ook die kern van die Nuwe Testament, die nuwe verbond en wat deur die doop aangedui word. Die gelowiges is saam met Hom begrawe in sy dood en het saam met Hom opgestaan in 'n nuwe lewe, met 'n nuwe gees, en het Hom lief (Rom. 6-8.) God se werk is lewewekkend. Die gelowige is iemand wat weer gebore is. Dit moet dan ook uitkom in ' $n$ wedergebore lewe. En dit moet gestalte kry in 'n lewe van 'n daaglikse nuwe geboorte, 'n lewe van bekering, van afsterwing van die sondige mens en 'n opstanding van 'n nuwe mens wat volgens die wil van God lewe.

Aangesien die eintlike besnydenis die van die hart is, is nie alle besnedenis ware verbondskinders nie, byvoorbeeld Ismael, en is die verbond nie tot die vleeslike nageslag van Abraham beperk nie, soos die geskiedenis van Ragab en Rut bewys (Jos. 2, Rut 1-4). Dieselfde geld van die doop in die Nuwe Testament. 


\section{DIE VERBONDSLUITING BY SINAI}

God se verbondsverhouding met Abraham vorm die basis van die verbonảsluiting, of verbondsvernuwing, by Sinai.12 Wanneer God vir Moses roep om Israel uit Egipte uit te lei, iets wat uitloop op die verbondsluiting by Sinai, dui God Homself aan as die God van Abraham, Isak en Jakob (Eks. 3:6, 15). Die rede waarom God vir sy volk intree, is volgens Eks. 2:24 dat $\mathrm{Hy}$ aan ssy verbond met Abraham, Isak en Jakob gedink het.

Die verbondsluiting by Sinai rus dus in 'n Goddelike verbintenis wat reeds bestaan het. Eksodus 19, die hoofstuk wat direk voorafgaan aan die hoofstuk oor die tien gebooie en die verbondsluiting by Sinai, stel die saak duidelik en is baie belangrik vir ons onderwerp. Behalwe dat God met die aartsvaders 'n verbond gesluit het, was Hy voor die verbondsluiting by Sinai reeds verkiesend en verlossend aan sy volk werksaam. Voordat God die verbond met Israel by Sinai oprig sê $\mathrm{Hy}$ dat $\mathrm{Hy}$ hulle toe reeds wonderdadig uit Egipte verlos en hulle op arendsvlerke gedra en na Hom toe gebring het (Eks. 10:4). Deuteronomium 7:7, 8 stel dit soos volg: 'Die Here het 'n welgevalle aan julle gehad en julle uitverkies, nie omdat julle meer was as al die volke nie, want julle was die geringste van al die volke. Maar omdat die Here julle liefgehad en die eed gehou het wat Hy vir julle vaders gesweer het, het Hy julle . . . verlos". Net soos by Abraham neem God die volle inisiatief en voer $\mathrm{Hy}$ die saak deur. Net soos by Abraham sluit die Goddelike verkiesing ook hier nie uit dat God voorwaardes aan sy volk stel nie. Hy sê inteendeel: "As julle dan nou terdeë na my stem luister en my verbond hou, sal julle my eindom uit al die volke wees" (Eks. 19:5). Soos by Abraham kan die verhouding ontbind word as die volk die verbondsbepalings nie nakom nie (Gen. $17: 14$ ). Die menslike verantwoordelikheid verval dus nie, maar hierdie menslike aandeel is tegelykertyd ten diepste die vrug van die Goddelike inisiatief en werksaamheid. Dit is God self wat hulle na Hom toe gebring het nog voordat Hy hulle hierdie verantwoordelikheid opgelê het (Eks. 19:4).13

God stel dit by hierdie geleentheid duidelik aan Israel dat God enige volk as sy eiendom kan kies as $\mathrm{Hy}$ sou wou, want die hele aarde is Syne (Eks. 19:5). As Skepper het Hy reg daarop. Bowendien het Hy 'n besondere seggenskap oor Israel, want $\mathrm{Hy}$ het hulle uit Egipte gered. Hulle is sy besondere eiendom uit alle volke en moet vir Hom 'n heilige nasie wees (Eks. 19:6); dit wil sê hulle moet op 'n heel besondere wyse met Hom lewe en Sy eer in die wêreld bevorder. Dit moet gestalte kry in onderhouding van die verbondsbepalinge, in besonder die tien gebooie (Eks. 2:1, 2 e.v.) Die tien gebooie raak die regte verhouding tot God - algehele toewyding aan Hom alleen - en die regte sedelik-godsdienstige verhouding tot die naaste.

Israel moet 'n koninkryk van priesters wees (Eks. 19:6): hulle moet die nasies met God versoen, en het dus 'n sendingtaak; dit kom tot volle vervulling wanneer Jesus aan sy apostels gee om aan mense uit al die nasies die evangelie te verkondig en dié wat glo, te doop (Matt. 28:19); verder moet elkeen 'n koning en priester wees, 
elkeen moet God regstreeks dien deur kennis van sy verbondsbepalings en deur persoonlike gemeenskap met Hom.

Die voorgaande wys dat die tien gebooie nie maar sommer verpligtinge was wat op Israel gelê is nie, maar verbondsbepalings wat uitdrukking gegee het aan die verbondsverhouding tussen God en sy volk. Dit kom ook baie duidelik uit in die inleidingswoorde tot die tien gebooie in Eks. $20: 2$ : "Ek is die Here jou God, wat jou uit Egipteland uit die slawehuis uitgelei het". Omdat God met Israel in 'n verbondsverhouding staan, omdat $\mathrm{Hy}$ hulle reeds bevry het uit Egipte, omdat Hy reeds hulle God is, daarom ontvang hulle sy gebooie. Hulle kan daaruit lewe uit dankbaarheid vir sy groot verlossingswerk aan hulle en sy verbondsverhouding met hulle.

\section{DIE VERBOND MET DAWID}

By die verbond van God met Dawid (Jes. 55:3; 2 Sam. 7) is daar 'n toespitsing van die verbond deurdat die verwagtings op 'n persoon uit Dawid se geslag konsentreer. Ook hier is kontinuiteit met God se bestaande verbondsverhouding vanuit die verlede. God verwys onder meer uitdruklik na sy verhouding met Israel sedert die uittog uit Egipte (2 Sam. $7: 7$ ). Ook by die verbond met Dawid gaan dit om God se inisiatief: Dawid het wel gedink om vir God 'n huis te bou, maar God sal inteendeel vir Dawid 'n huis bou, 'n koninklike nageslag (v. 11, 12). God doen dit ter wille van sy woord en volgens sy hart (v. 21).

Ook hier gaan dit nie bloot om uitwendige verpligtinge wat nagekom moet word nie: God wil nie bloot in 'n tempel woon en deur 'n kultiese diens gedien word nie. Hy wil onder mense woon, Hy sal ' $n$ besondere verhouding tussen Hom en Dawid se seun daarstel, 'n vader-kindverhouding, 'n verhouding van verbondsliefde (hesed) (v. 14, 15). Ook hier is sprake van menslike verantwoordelikheid: as die seun van Dawid verkeerd handel, sal God hom straf (v. 14), maar ook hier gaan dit om 'n onverbreeklike band, een wat vir altyd vasstaan (v. 16, 24 e.v.) In hierdie hoofstuk word die woord 'ôlām dikwels en met nadruk gebruik. En hoewel dié woord op sigself nie ons begrip "ewigheid" hoef uit te druk nie, het dit hier tog ' $n$ besondere betekenis. Dawid bid hier byvoorbeeld dat God die belofte in vervulling moet laat gaan vir altyd (in ewig. heid) sodat sy Naam groot kan wees vir altyd (tot in ewigheid) (v. 25, 26). Hierdie belofte van God aan Dawid vorm die basis van die messiaanse verwagting wat sterk aan die Dawidshuis gekoppel is (bv. Jes. $9: 1$ e.v.; $11: 1$ e.v.; Jer. $23: 6$; Eseg. $17: 22-24 ; 34: 11$ e.v.; Am. $9: 11$; Miga $5: 1$ e.v.; Hag. $2: 21-24$; Sag. $9: 9$ e.v.).14

\section{DIE NUWE VERBOND}

Jeremia verkondig dat die volk Israel totaal korrup is deur die sonde $(2: 2-6,11,13 ; 13: 23 ; 18: 14,15)$. Daar is 'n eksistensiële verandering nodig, 'n wesenlike verandering van binne uit (vgl. $31: 28$ met $1: 10$ ). Dit vereis bekering, iets wat die mens self moet doen maar wat tog alleen deur die Here bewerkstellig kan word Daarom bid die volk: "Bekeer my, dan sal ek my bekeer, want $U$ is die Here my God" $(31: 18)$. Die Here gaan hulle hart verander; Hy 
gaan sy wet in hulle binneste gee en dit op hulle hart skrywe (31:34). Hierdie optrede van Hom is 'n nuwe verbondsluiting en wel omdat sy volk die bestaande verbond verbreek het $(31: 31,32)$. Tog is daar geen wesenlike verskil met die oue nie. Dit gaan in die nuwe verbond net soos in die oue daarom dat God hulle God sal wees en hulle sy volk sal wees $(31: 33)$. Die verskil is slegs dat $\mathrm{Hy}$ hulle van binne uit gehoorsaam gaan maak. Ook in die verbond met Abraham en die verbond by Sinai is die gehoorsaamheid ten diepste n vrug van God se optrede, soos reeds aangetoon is, maar nou gaan God nog ingrypender in die mens werk. Dit is nie ' $n$ meganiese of onpersoonlike werking of verandering nie, maar die bewerking van in gesindheidsverhouding in 'n persoonlike verhouding.

God se optrede hier rus in sy vergewende genade (Hy sal sy volk se ongeregtighede vergewe en aan hulle sonde nie meer dink nie $(31: 34)$, en dit geld alleen vir die oorblyfsel $(31: 7)$. Die oorblyfsel is nie bloot dié wat letterlik oorgebly het nie, maar dié wat uitgered is uit die sonde, uit die ondergang en dood in hulleself, sodat hulle nuwe mense geword het wat in hulle harte verander het.

Die gedeelte oor die nuwe verbond verkondig dus dat daar alleen verlossing is deur God se lewewekkende optrede. Alles rus in sy inisiatief, in sy verbondsliefde wat deur niks ongedaan gemaak kan word nie, selfs nie deur sy volk se ontrou aan die verbond nie, selfs nie al straf Hy die volk met 'n streng straf vir hulle cntrou nie.

Esegiël sê God sal dit doen deur hulle met skoon water te reinig en deur hulle sy wet te laat onderhón deur sy Heilige Gees (Eseg. $36: 25,26$ ).

Uit die voorgaande blyk dus dat die verhouding tussen God en sy volk wesenlik dieselfde sal bly in die nuwe verbond, dat God alle inisiatief neem, heeltemal vrymagtig optree in sy verkiesende $\in n$ vergewende genade en dat Hy die gawe gee maar tegelyk bewerk dat die mens sy verpligtinge nakom. Verder word die bekering en vergewing en reiniging in verband gebring met water en met die Heilige Gees, soos by die doop in die Nuwe Testament. ${ }^{15}$

\section{VERBOND, DAG VAN JAHWE EN LYDENDE KNEG}

In die res van Jeremia en by ander profete word sterk nadruk gelê op die verbondsvolk se ontrou, onwilligheid en onmag. Daarom is daar sterk verwagtings na die Dag van die Here. Die geskiedenis van die verbondsvolk loop onkeerbaar uit op die groot en onheilspellende dag van afrekening. Tog is dit maar een kant van die saak. Ondanks hulle aankondiging van die vernietigende oordeel gaan die profete nie so ver om te sê dat die Here sy volk heeltemal verwerp het nie. In sy vrymagtige genade hou Hy sy hand aan sy volk. In die knegliedere in Jesaja $(42,49,50,53)$ word sekere lig hierop gewerp.

Die volk is die kneg van die Here in wie Hy bedoel om gestalte te gee aan sy heerskappy waarin die lig vir alle nasies aanbreek $(42: 6)$. So het Hy by die roeping van Abraha mbeloof (Gen. $12: 3$ ). Die kneg Israel sterf en staan op $(53: 10,11)$ deurdat hy uiteindelik as volk in die ballingskap ondergaan, sterf en tog wonderbaarlik deur die Woord en Gees van die Here herleef en uit die bal- 
lingskap gered word (Eseg. 37). Wat van die kneg gesê word, gaan egter bo die volk en hierdie gebeurtenis uit en sal in 'n persoon vergestalt word.

In die kneg as persoon word die hele verbond met die volk saamgetrek en word ondergang sowel as verlossing verwerklik, of beter gestel: verlossing deur ondergang heen. Die Here sal sy Gees op hierdie kneg lê en hom as 'n "verbond van die volk" gee (Jes. $42: 6$ ). Die hele verbond word in die kneg saamgevat, al die seëninge daarvan word in hom werklikheid. Hy is die verpersoonlikte verbond. En $\mathrm{Hy}$ is dit op ' $\mathrm{n}$ unieke manier. Hy is priester maar een wat self die offerlam is; $\mathrm{Hy}$ is koning, maar een wat optree as 'n lydende kneg; Hy is profeet, maar een wat sy mond nie oopmaak nie. Hierdie kneg sal ly en sterf deur die optrede van die volk en tegelykertyd ter wille van hulle (Jes. 53:1 e.v.) Sy dood is 'n skuldoffer. Hy dra hulle skuld en maak hulle regverdig $(53: 10,11)$. Ná die dood leef $\mathrm{Hy}$ weer (v. 10). Hy gaan dus vir die volk die dood in en deur die dood heen die lewe in.

Dit gebeur in Jesus Christus. In die Nuwe Testament pas Filippus hierdie gedeelte wat deur die Etiopië op 'n wa gelees is, op Jesus ioe, en die vrug daarvan is dat die Etiopiër gedoop word (Hand. 8: 26 e.v.) So word hy ingelyf by Jesus, die lydende kneg van die Here, die verbond van die volk. ${ }^{10}$

\section{DIE SEUN VAN DIE MENS}

In Dan. 7 is daar ' $n$ soortgelyke verbinding as in die knegliedere, 'n verbinding tussen die verbondsvolk en 'n persoon wat bo die volk uitgaan. Volgens 7:18 sal die heerskappy oor die aarde gegee word aan die "heiliges van die Allerhoogste", en volgens $7: 13,14$ aan die "seun van die mens". Die "heiliges van die Allerhoogste" is die lede van die verbondsvolk, vir wie God uit Egipte geroep het om 'n heilige nasie te wees (Eks. 19:6). Die uitdrukking "seun van die mens" dui iemand aan wat tot die kategorie mens behoort net soos die uitdrukking die seuns/kinders van Israel" mense aandui wat tot Israel behoort, Israeliete. "Seun van die mens" beteken dus die "mens" en slaan op iemand wat die ware mens is, die ware verteenwoordiger van die mensdom en van die verbondsvolk. Die ware mens sal menslik wees in sy heerskappy, anders as die wêreldryke wat dierlik is en in hierdie hoofstukke as diere voorgestel word. Hy is die ware mens maar is van hemelse herkoms, Hy kom met die wolke ( $7: 13)$, en die lede van die verbondsvolk regeer saam met hom. Hulle is uit die ondergang gered en regeer as mense wat as't ware lewe uit die dood ontvang het. Hulle is self van die begin af ' $n$ halstarrige en verdorwe volk, en daarom het die vloek wat op oortreding van die verbond rus, hulle getref, soos dit in die wet van Moses geskrywe is $(9: 11$ e.v.;.) God sal daarom 'n nuwe bedeling laat aanbreek met die koms van die "Seun van die mens". Hy sal in die verbondsvolk self as't ware lewe uit ondergang bewerk, stoflik en geestelik.

Ons vind by verskillende profete die tendens dat die woord wat die profeet moet bring, in die profeet self 'n sekere vergestalting kry: Jeremia mag nie trou nie, 'n teken van die eensaamheid 
wat die volk gaan tref. Esegiël mag om 'n soortgelyke rede nie oor die dood van sy vrou rou nie. Hosea se huwelik met 'n prostituut bring iets van God se verhouding met die ontrou Israel tot persoonlike vergestalting. In Jes. 53 en Dan. $7 \mathrm{kom}$ die woord, die verbond, tot persoonlike vergestalting in iemand wat een is met die volk maar tog die volk transendeer. ${ }^{17}$

Hierdie openbaring trek uiteindelik saam in Jesus Christus, in Hom het die Woord mens geword. Dit trek ook saam in die Heilige Gees as persoon, nie as 'n blote krag van Christus of van God nie. Die onderskeid tussen God en die Gees en tussen Christus en die Gees bly gehandhaaf; die Gees het as persoon gekom. Die Heilige Gees vervang nie die Woord van die Ou Testament nie, ook nie vir Christus nie, maar tree op in verbinding met die Woord, met Christus.

\section{MET DIE KOMS VAN JESUS KOM DIE DAG VAN DIE HERE}

Die bedeling van die Ou Testament loop uiteindelik uit op die Dag van die Here, soos ons onder andere in die laaste verse van Maleagi die laaste boek in die ry van die profete, lees. Maleagi verbind dié dag aan Moses en Elia (Mal. 4:4,5), die verteenwoordigers van die wet en die profete. Die Verkondiging van die wet en die profete spits toe op die Dag van die Here as straf op die verbondsvolk se verbreking van die verbondsverhouding met God. Voor die koms van dié dag sal God egter 'n boodskapper stuur om die volk tot bekering op te roep (Mal. 3:1). Jesus sê dat hierdie profesie op Johannes die Doper betrekking het (Matt. $11: 10$ ). Hy is Elia wat volgens Maleagi die volk vir die oordeel van dié dag moet waarsku sodat hulle hulle bekeer en die vernietiging vryspring (Matt. $11: 14$; Mal. 4:6).

Johannes die Doper kondig Jesus aan, en Jesus sê in hierdie Skrifgedeelte omtrent Homself dat Hy die Seun van die mens is (Matt. 11:19). In 'n latere gesprek sê Jesus dat die Seun van die mens ook deur die volk sal ly (Matt. 17:12). Hy sal in sy heerskappy eers later kom, in die eskatologiese toekoms (Matt. 24:29). In Hom word die profesie van die lydende $\mathrm{kneg}$, van wie Jesaja geprofeteer het, vervul (Matt., $8: 17$; Mark. 15:28; Rom. $4: 24,25$ ). In al drie die sinoptiese evangelies gaan die Jesus se prediking oor die komende oordele wat die Dag van die Here inlui, byna onmiddellik vooraf aan Jesus se lydensgeskiedenis (Matth. 24; Mark. 13; Luk. 21). ${ }^{18}$ En in Hand. 2:19 wys Petrus op die beskrywing van die Dag van die Here in Joël 2 waarvolgens dié dag ingelui sal word deur wonders wat gepaard gaan met die uitstorting van die Heilige Gees. Petrus verbind dit dan verder met Jesus se kruisdood en opstanding (Hand. $2: 23$ e.v.). In Christus het die Dag van Jahwe dus aangebreek, die straf en lyding daarvan, asook die verlossing wat Christus deur sy vloekdood en sy opstanding bewerkstellig het $(2: 32$ e.v.) Om hieraan deel te hê, moet die hoorders hulle bekeer en hulle in die Naam van Jesus Christus laat doop $(2: 37,38)$. So word die belofte van vroeër vir hulle 'n werklikheid $(2: 39)$. Die doop kom dus nou na vore as die aanduiding van die toebehorenheid tot die verbondskring. 
Uit hierdie gedeelte blyk dat die doop op die mislukking van die mens wys soos dit tot uiting gekom het in Israel, Israel wat in die ou bedeling 'n oorblyfsel en verteenwoordiger van die mensdom is. Verder dui die doop op die oordeel wat voltrek is: die Dag van die Here wat op Jesus Christus afgekom het. Verder dui die doop op die vergewing, afwassing van die sonde, en op reiniging va ndie lewe in die eis van gehoorsaamheid.

Hier moet nog nader ingegaan word op: Jesus en die verbond.

\section{JESUS EN DIE VERBOND}

Die geboorte van Jesus Christus en dié van Johannes die Doper word deur Maria en Sagaria onderskeidelik gesien as God se optrede kragtens sy verbond sedert Abraham (Luk. $1: 54,55 ; 1: 72,73$ ).

Die verbond trek ten diepste saam in Christus en alles wat God in Hom aan die mens gee. ${ }^{19}$ Christus is die ware saad of nakomeling van Abraham (Gal. 3:16). Die skrywer van Mattheus lê deur die geslagsregister van Christus daarop nadruk dat Christus die seun van Abraham is (Matt. 1:1). Lukas lê in die geslagsregister wat hy gee, nadruk daarop dat Jesus die seun van Adam is en lê dus 'n nog wyer verband as net Israel, naamlik 'n universele verband (Luk. 3:38). Johannes gaan nog verder terug as Adam en lê die transendente verband: Jesus is die Woord wat mens geword het (Joh. $1: 1$ e.v.). Hy is die Seun van God $(1: 17,18$; vgl. ook v. 34). Jesus is volgens Johannes tegelykertyd die "lam van God" $(1: 29,35)$; Hy is die eintlike Paaslam (Eks. 12:5), wat vir ons geslag is (1 Kor. $5: 7-8$ ), die lydende kneg wat geslag is vir die sonde van baie mense (Jes. $53: 7-12$; Hand. $8: 32$ e.v.! 1 Petr. $1: 18-19)$. Hy is die kneg wat gegee is as 'n verbond van die volk (Jes. 42:6), dit wil sê in wie die verbond beliggaam is, persoonlik gestalte gekry het. Wie aan hom deel het, het deel aan alles wat in die verbond beloof is. Sy bloed wat aan die kruis gestort is, is die bloed van die nuwe verbond (Matt. 26:28; vgl. ook Eks. 24:8), dit wil sê die bloed waardeur die verbond 'n nuwe gestalte aanneem, soos reeds in die Ou Testament deur Jeremia beloof is (Jer. $31: 27-34$ ).

Jesus Christus is egter nie met die inhoud van die verbond nie, $\mathrm{Hy}$ kom nie net as vervulling van die verbondsbelofte nie; $\mathrm{Hy}$ is ook die basis van die verbond. $\mathrm{Hy}$ is nie net die vrug van die verbondsbeloftes nie, maar dié is ' $n$ vrug van Hom. Hy, sy bestaan, gaan terug tot voor die verbond, want $\mathrm{Hy}$ is nie net die seun van Abraham nie, maar ook die seun van Adam en ook die Seun van God. Hy is nie net die vervulling van die verbond nie, maar Hy beheers die verbond. $\mathrm{Hy}$ is Here van die verbond soos Hy Here is van die sabbat (Matt. 12:8). Hy het wel nie gekom om die wet en die profete, die verbond, te ontbind nie, ongeldig te maak nie ,maar om dit te vervul, die volle betekenis te laat kry (Matt. 5:17). Sy koms is so ingrypend en beheersend dat ' $n$ mens by Hom ingelyf moet word om deel aan die verbond te hê. Daarom kom daar met sy koms 'n nuwe teken van die verbond, naamlik die doop (Hand. 2 : 37-39; Matt. 28:19). Net soos by die verbond in die Ou Testament mag niemand hierby onbetrokke bly nie, want dan volg die oordeel (Hand. $2: 37,38$; Mark $16: 16$ ). 
Die besnydenis, net soos die paaslam, word vervang met 'n nuwe teken wat direk met Christus verbind word. Die gelowiges van die nuwe bedeling ontvang nou die besnydenis van Christus. Dit bestaan in die wegneem van hulle sondige natuur deurdat hulle by hulle doop saam met Christus begrawe word. Deur hulle verbondenheid met Hom word hulle weer opgewek deurdat hulle glo in die opstandingskrag van God waardeur Hy Christus uit die dood opgewek het (Kol. 2:11, 12). Dit gaan wesenlik om dieselfde as by Abraham (vgl. veral Gen. 22).

Hebr. 8:13 praat van die nuwe verbond waardeur die eerste oud gemaak is en uitgedien raak. ${ }^{20}$ Dit raak alleen die bykomstige elemente. Hier word uitdruklik 'n verband gelê tussen die nuwe verbond en die verkondiging daarvan deur Jeremia (31:31-34). Soos reeds by die bespreking van Jer. $31: 31-34$ gesien is, verskil die nuwe verbond nie wesenlik van die oue nie. Die boek Hebreërs het dit teen die wettisistiese letterknegtery, net soos Paulus in 2 Kor. $3: 6$, en teen ' $n$ vasklemming aan skaduagtige en onwesenlike elemente van die verbond. Jesus Christus is priester, profeet en koning tegelykertyd, meer as Aäron, Moses en Dawid (Hebr. 4:14-16; $5: 1$ e.v.; 7 : $17 ; 3: 3 ; 1: 1$ e.v.).

\section{DIE VERBOND EN DIE DRIE-EENHEID}

Ons het reeds gesien dat die openbaring van God histories en persoonlik gestalte gekry het met die koms van Jesus Christus. God het Hom so nou en persoonlik met die mens verbind dat Hy op 'n unieke manier in die geskiedenis ingekom het: die Woord wat God is, het vlees geword, mens geword. Daar het 'n gebeurtenis plaasgevind wat so ingrypend van aard is dat dinge nie meer dieselfde kan bly nie. Daar het nie slegs 'n ander idee gekom of 'n verandering in ' $n$ idee plaasgevind nie, maar daar het 'n historiese gebeurtenis plaasgevind. Christus as persoon het gekom; daar het histories en persoonlik ' $n$ verandering ingetree. Tog bly daar kontinuïteit in God se optrede, in die openbaringsgeskiedenis.

Die verhouding tussen die ou bedeling en die nuwe bedeling is dat God in die ou bedeling ongedifferensieerd optree en in die nuwe bedeling openbaringhistories gedifferensieerd, naamlik as Vader, Seun en Heilige Gees. Christus en die Heilige Gees het nou in die lewe van die gelowige ' $n$ betekenis wat gedifferensieerd is van dié van die Vader, hoewel dit nie daarvan geskei is nie. Christus verbind die doop uitdruklik aan die Drie-eenheid: "Gaan dan na al die nasies toe en maak die mense my dissipels: doop hulle in die Naam van die Vader en die Seun en die Heilige Gees" (Matt. 28 ... 19).21.

Die doop word nie net aan Christus verbind of net aan die Heilige Gees of net aan Christus en die Gees, asof daar 'n streep getrek is deur God se verbondsverhouding waarin Hy sedert die ou bedeling tot die gelowiges staan nie.

Moltmann sien nie net 'n differensiëring in die Drie-eenheid nie, maar hy sien die Drie-eenheid as't ware as ontwikkelingstadia in God self. ${ }^{22}$ Die stadium van Christus vervang eintlik dié van die Vùder, en dié van die Heilige Gees vervang eintlik diê van Christus. 
Die Heilige Gees woon nou in die mens ,en die mens is nou baie selfstandiger teenoor God. Daarom verkies Moltmann om nie te praat van 'n Vader-kindverhouding tussen God en mens nie, maar van 'n vriendsverhouding. ${ }^{23}$

Hierdie benadering van Moltmann is die oorsaak daarvan dat hy die kinderdoop betwyfel, ${ }^{24}$ want hy oorwaardeer die mens teenoor God, en dit maak dat die absolute inisiatief van God, sy verkiesende genade en sy blywende verbondstrou nie tot hulle reg kom nie. Hierdie leemte geld ook vir die benadering van almal wat die kinderdoop verwerp.

Dit is wel waar dat die gelowige in 'n sekere opsig 'n vriend van God is. Dit geld egter nie net vir die Nuwe-Testamentiese situasie nie, maar word reeds van Abraham gesê (Eks. 33:11). Dit is egter slegs in ' $n$ heel beperkte opsig die geval. Abraham se verhouding tot God word gekenmerk deur algehele afhanklikheid, só dat God alle inisiatief het, en sy verhouding met Abraham selfs ook vir sy kinders geld.

Die leemte waarvan hierbo sprake was, is in direkte stryd met die gebed wat Jesus ons geleer het, naamlik die Onse Vader: God is ons Vader, ons is sy kinders. Hierdie verhouding is in die $\mathrm{Ou}$ Testament nie onbekend nie, maar word daar meer indirek as direk gebruik (Eks. 4:22; Spr. 3:12; Mal. 1:6 en nie as aanspreekvorm (vokatief) nie. Deur Jesus Christus kom die volle werklikheid hiervan na vore.

Dié gebed wys dat Jesus nie iets anders bring as die Ou Testament nie, en dat Christus en die Heilige Gees ook nie bloot iets ckstra bring by die Ou Testament nie:25 Christus en die Heilige Gees het in hierdie gebed nie 'n plek naas ander dinge waarvoor gebid word nie maar het ' $n$ beheersende plek in die gebed as geheel. Nog Christus nog die Gees word in die gebed by name genoem. Maar dit is wel 'n gebed in die Naam van Christus, dit word op sy gesag gebid en in Hom word ons hele verhouding tot God bepaal. Hý leer en beveel ons om God aan te spreek as: Ons Vader (Matt. 6:9). En dit is alleen deur die Heilige Gees dat ons daartoe kom om God so aan te spreek, sê Rom. 8:15. Hierdie Gees getuig saam met ons gees dat ons kinders van God is. En omdat ons kinders is, is ons ook erfgename (Rom. $8: 15,16$ ).

Die voorgaande wys tegelykertyd dat daar nie net met God in sy gedifferensieerdheid as Vader, Seun en Heilige Gees rekening gehou moet word nie, maar ook met God in sy eenheid. Hy moet nie prakties in drie, Vader, Seun en Heilige Gees, opgedeel word nie. Dan word daar rondgedobber tussen 'n Vader-godsdiens, 'n Christusgoedsdiens en 'n Heilige Gees-godsdiens. Daar is maar een God, en wat Hy doen, is 'n eenheid. Ons moet ons aan die een God oorgee en Hom mel ons hele hart en siel dien. Hý het met ons die verbond gesluit en Hy verwerklik dit deur die onderskeidende aldrie van Vader, Seun en Heilige Gees.

\section{DIE BETEKENINS VAN DIE OU TESTAMENT EN VAN DIE DOOP IN DIE PRAKTYK.}

Uit die voorgaande is dit duidelik dat daar kontinuiteit in God se 
verbondsverhouding met die mens is dwarsdeur die openbaringsgeskiedenis. Die Nuwe Testament veronderstel die Ou Testament. As die gelowiges nie genoegsame kennis van die Ou Testament het nie, hang die Nuwe Testament, byvoorbeeld die doop, in die lug. Daarom moet die Ou Testament voldoende aandag kry, ook in die prediking. Ook moet die openbaringshistoriese verbande vanuit die $\mathrm{Ou}$ Testament in die Nuwe Testament duidelik aangedui word.

Die Drie-eenheid moet in ons prediking differensiërend gespreek word. ${ }^{20}$ Elke preek moet Vader, Seun en Heilige Gees uitdruklik preek. So kom die liefde van God, asook die versoening van sondes en God se lewewekkende werking in ons lewe, gepaard met die oproep tot bekering en 'n heilige lewe, tot sy reg. En deur sodanige prediking word die Heilige Gees nie los van Christus en los van die Woord verkondig of deur die gemeente beleef nie. Deur so 'n prediking kan die gemeente gevoed word met en deur die Heilige Gees sonder dat in charismatiese vaarwaters beland word. Dit hou in dat daar nie net differensiërend oor God as drie-enige God gepreek moet word nie, maar ook so dat die eenheid van God tot uiting kom.

Die doop moet so gehanteer word dat die gedooptes hulle geanker weet in God se werk uit die verlede, maar dat hulle ook aangemoedig word tot lewenskragtigheid nou, en boonop 'n lewende hoop het op die toekoms. Die gedooptes moet ook in 'n antitese staan met die sonde binne hulle en buite hulle. Hulle moet besef dat God 'n gelowige lewenspatroon vereis en dat Christus, wat die doopbevel gegee het, ook sal terugkom en dat $\mathrm{Hy}$ dié wat nie glo nie, sal oordeel. Die doop impliseer lering, bemoediging, opskerping vermaning, onderlinge tugtiging en ook tugtoepassing. Die doop impliseer inlywing by Jesus Christus en sy liggaam, sy gemeente.

Dit veronderstel 'n ware verbondslewe, 'n lewe in 'n lewende aktiewe verbondenheid met God en sy gelowiges. Dit impliseer verder 'n lewende gemeente, 'n gemeentlike lewe waari ndie gedoopte hom betrokke voel en waarin hy warmte vind.

\section{IITERATUUR:}

i. Vgl. J. L. Heiberg. Verklaring en prediking van die Ou Testament. Potchefstroomse Teologiese Publikasies. Potchefstroom, 1983, 92 e.v. 
2. Vgl. J. L. Helberg. Verklaring en prediking van die Ou Testament, en Die Here regeer. Openbaringslyn deur die Ou Testament. N. G. Kerkboekhandel Transvaal, 2 1983, 4 e.v.

3. G. von Rad le te veel nadruk hierop, ten koste van diê op God as Skepper, en verklaar daarom die Ou Testament ten onregte soteriologies; vgl. J. L. Helberg, Verklaring en prediking van die Ou Testament, 26 e.v., 23.

4. Vgl. G. von Rad. Das Alte Testament ist ein Geschichtsbuch. In: C. Westermann, red. Probleme altestamentlicher Hermeneutik. Munchen, 1968, 11-17.

5. Vgl. vir hierdie en die volgende bespreking, F. $N$. Lion-Cachet. Die kontinuïteit van die Abrahamitiese verbond in die opset van die Sinaïtiese verbond. Proefskrif PU vir CHO, 1977, 5 e.v.; Th.C. Vriezen. Hoofdlijnen der Theologic van het Oude Testament. ${ }^{3}$ Wageningen, 1966, 181, e.v.; 380 e.v.; D. J. Mc Carthy. Old Testament Covenant. A survey of current opinions. Oxford, 1973; en verder die Hebreeuse woordeboeke en teologiese woordeboeke soos THAT en ThWAT.

6. Vgl. hiervoor en veral ook vir die betekenis van die uitverkiesing, J. Bright. The authority of the Old Testament. London, 1967, 126 e.v.

7. Vgl. Helberg. Die Here regeer, 78 e.v.

8. Vgl. vir hierdie en die volgende bespreking, F. N. Lion-Cachet, 148; S. du Toit. Openbaringsgeskiedenis van die Ou Testament.4 Potchefstroom, 1969, 120 e.v.

9. Vgl. Helberg. Die Here regeer, 54.

10. do, 52.

11. Vgl. ook L. Floor. Die heilige doop in die Nuwe Testament. Potchefstroomse Teologiese Publikasies. Potchefstroom, 1983, 13, 15, 17.

12. Vgl. Lion-Cachet, 262 e.v., Du Toit, 128 e.v.

13. Vgl. Helberg, Die Here regeer, 77 e.v.

14. Vgl. vir meer besonderhede, Helberg, Die Here regeer, 126 e.v.

15. Vgl. Floor, 2.

16. Vgl. ook J. L. Helberg. Die val van Jerusalem en die Dag van Jahwe. Proefskrif PU vir CHO, 1965, 217 e.v.

17. Vgl. W. J. Snyman. Die prediking van Paulus - openbaringshistories. In: Die Goue Kandelaar. Jaarblad van die Teologiese Studentevereniging van die Gereformeerde Kerk in Suid-Afrika. Nr. 7, 11-16.

18. Vgl. ook H. Berkhoff. Christus de zin der geschiedenis,4 Nijkerk, 1962, 59.

19. Vgl hier en by die volgende, Lion-Cachet, 308 e.v.

20. Vgl. Floor, 96 e.v.

21. Vgl. ook Floor, 27 e.v.

22. Vgl. J. Moltmann. The church in the power of the Spirit.2 1978, 62 e.v.

23. Moltmann, 118.

24. Moltmann, 226 e.v., 240 e.v.

25. Vgl. J. L. Helberg. Die Ons Vader: Die Heilige Gees is geen ekstra nie. Die Kerkblad, 26 Augustus 1981.

26. Vgl. Helberg. Verklaring en prediking van die Ou Testament, 107 e.v. 